\begin{tabular}{|l|l|l||}
\hline \multicolumn{2}{|c|}{ PublisherInfo } \\
\hline \hline PublisherName & $:$ & BioMed Central \\
\hline \hline PublisherLocation & $:$ & London \\
\hline \hline PublisherImprintName & $:$ & BioMed Central \\
\hline \hline
\end{tabular}

\title{
Monkey map
}

\begin{tabular}{|l|l|l||}
\hline \multicolumn{2}{|c|}{ ArticleInfo } \\
\hline \hline ArticleID & $:$ & 4369 \\
\hline \hline ArticleDOI & $:$ & $10.1186 /$ gb-spotlight-20020104-01 \\
\hline \hline ArticleCitationID & $:$ & spotlight-20020104-01 \\
\hline \hline ArticleSequenceNumber & $:$ & 35 \\
\hline \hline ArticleCategory & $:$ & Research news \\
\hline \hline ArticleFirstPage & $:$ & 1 \\
\hline \hline ArticleLastPage & $:$ & 2 \\
\hline \hline & & RegistrationDate : 2002-01-04 \\
ArticleHistory & $:$ & OnlineDate \\
\hline \hline ArticleCopyright & $:$ & BioMed Central Ltd2002-01-04 \\
\hline \hline ArticleGrants & $:$ & \\
\hline \hline ArticleContext & $:$ & 130593311 \\
\hline \hline
\end{tabular}




\section{Jonathan B Weitzman}

Email: jonathanweitzman@hotmail.com

Following the completed draft of the human genome sequence, there is renewed interest in the genetic differences between species and, particularly, in what makes us human. In the January 4 Science, Asao Fujiyama and colleagues at the RIKEN Genomic Sciences Center in Japan present a first-generation human-chimpanzee comparative genome map (Science 2002, 295:131-134). They used over 77,000 chimp bacterial artificial chromosomes (BAC) and aligned end-sequences with the human genomic sequence. The BAC clones covered almost half of the human genome. They calculated that the degree of identity with human sequences is about $98.77 \%$. Closer analysis of chromosome 21 provided evidence for several human-specific loci. This map represents a step towards discovering what makes us different from our closest relatives, the apes.

\section{References}

1. Science, [http://www.sciencemag.org]

2. RIKEN Genomic Sciences Center, [http://www.gsc.riken.go.jp] 